ISSN (print): 1698-6180. ISSN (online): 1886-7995

www.ucm.es/info/estratig/journal.htm

Journal of Iberian Geology 38 (1) 2012: 52-69

http://dx.doi.org/10.5209/rev_JIGE.2012.v38.n1.39205

\title{
Seismicity and potencially active faults in the Northwest and Central-West Iberian Peninsula
}

\author{
Sismicidad y Fallas Potencialmente Activas en el Noroeste y Centro Oeste de \\ la Península Ibérica
}

\author{
F. Martín-González ${ }^{1}$, L. Antón², J.M. Insua ${ }^{3}$, G. De Vicente ${ }^{3}$, J.J. Martínez-Díaz ${ }^{3}$, \\ A. Muñoz-Martín ${ }^{3}$, N. Heredia ${ }^{4}$, A. Olaiz ${ }^{3,5}$ \\ ${ }^{1}$ Área de Geología. ESCET. Universidad Rey Juan Carlos. c/ Tulipán, s/n. Móstoles, 28933 Madrid, Spain \\ ${ }^{2}$ Grupo de Investigación en Tectonofisicica Aplicada. Facultad de Ciencias. Universidad Nacional de Educación a \\ Distancia. Paseo del Rey, 9. 28040 Madrid, Spain. \\ ${ }^{3}$ Dto. Geodinámica. Facultad de Ciencias Geológicas. Universidad Complutense de Madrid. c/ Jose Antonio \\ Novais, 2.28040. Madrid, Spain. \\ ${ }^{4}$ Instituto Geológico y Minero de España (IGME), c/Matemático Pedrayes, 25, 33005 Oviedo, Spain \\ ${ }^{5}$ Repsol Exploración S.A:, Paseo de la Castellana 278, 28046 Madrid, Spain
}

*Corresponding author: fidel.martin@urjc.es Fax:+34-916647490

Received: 05/01/2012 / Accepted: 05/03/2012

\begin{abstract}
The Northwest and Central-West Iberian Peninsula configure an intraplate area far from the active plate boundaries, where the Variscan basement crops out extensively (Iberian Massif). This area of the Iberian Peninsula has been traditionally considered a seismically stable region; however, it presents a moderate intraplate seismicity which indicates the presence of active structures and the occurrence of potentially damaging earthquakes. The scarcity of Mesozoic and Cenozoic deposits makes very difficult to track the record of the more recent tectonic activity and the characterization of active tectonic structures within the Iberian Massif. Nevertheless the seismic sequences of 1995-1997 in Lugo (5.1 mb; IV) and 2003 in Zamora (4.2 Mw) provided important information about the orientation of the present stress tensor, and the distribution of the hypocenters informed about the rupture geometry of the fault planes. The present work integrates geological, geomorphological, structural, and seismological data in order to define the main potentially active faults in the region. Faults trending NE-SW to N-S are potentially active as strike-slip, in some cases with a reverse component, under a NW-SE to N-S compression.
\end{abstract}

Keywords: Seismicity, Potentially active faults, Spain, Active tectonics, Neotectonics, Variscan basement

\section{Resumen}

El Noroeste y Centro Oeste de la Peninsula Ibérica son parte de una región intraplaca alejada de los bordes de placa sísmicamente activos, donde aflora el basamento varisco (Macizo Ibérico). Esta región de la Península Ibérica ha sido tradicionalmente considera- 
da sísmicamente estable; sin embargo, presenta una moderada sismicidad que indica la presencia de estructuras activas y terremotos potencialmente catastróficos. La escasez y dispersión de los depósitos Mesozoicos y Cenozoicos hace difícil identificar la actividad tectónica más reciente, así como la caracterización de las fallas potencialmente activas dentro del Macizo Iberico. Sin embargo la sismicidad de 1995 y 1997 en Lugo $(5.1 \mathrm{mb})$ y de 2003 en Zamora (4.2 Mw) aportó importante información para determinar la orientación del tensor actual de esfuerzos. De igual modo, la orientación de las replicas aportó información sobre los planos de rotura. El presente trabajo integra datos geológicos, geomorfológicos, estructurales y sismotectónicos para definir las principales fallas potencialmente activas en la región. Las fallas con orientaciones NE-SW hasta N-S son potencialmente activas, bajo un tensor de esfuerzos de NW-SE a N-S, como fallas de desgarre y en algunas zonas con componente inversa.

Palabras clave: Sismicidad intraplaca, Fallas potencialmente activas, España, Tectónica activa, Neotectónica, Basamento varisco

\section{Introduction}

The North-West and Central-West regions of the Iberian Peninsula are located far away from the seismically active borders of the Iberian microplate (Fig. 1) and have been traditionally considered a stable intraplate area with no significant seismicity. However, seismic sequences of moderate magnitude have revealed the presence of active structures and potentially damaging earthquakes in this region where, in addition, no preparation or seismic education exist to mitigate the risk. Recently, seismicity in intraplate regions has been the focus of scientific studies due to the unexpected and relevant destruction that can be generated by moderate magnitude earthquakes. Examples in the last years are Ungava in 1989, Latur in 1993 and Kutch in 2001 (Adams et al. 1991, Crone et al., 1992, Gupta, 1993). This evidenced the necessity for the revision of the seismic catalogues and active structures in intraplate areas where earthquakes have very long seismic cycles and seismotectonic studies are scarce.

The unexpected intraplate activity in Lugo during 1995-1997, with a maximum magnitude event of $5.1 \mathrm{mb}$ (VI), and Zamora during 2003 with a maximum magnitude event of $4.2 \mathrm{Mw}$, point out the necessity of a better knowledge of the potentially active tectonic structures were seismicity may occur. In this way, the seismic sequences of Lugo in 1995 and 1997 promoted the revision of the Spanish building design standards (NCSE-94) published just only one year before the Lugo events, and the publication of a new regulation in 2004 (NCSE-2002).

In the study area, the existing fault pattern is the result of a long deformational story developed during Variscan and Alpine orogenies. In this type of highly fractured basements the reactivation of previous faults, favorably oriented to the current stress tensor, is the main deformation mechanism, instead of generation of new faults (De Vicente et al. 2007). With low slip-rate faults, and low seismic cycles, the erosion processes are faster than the tectonic processes that generate scarps or other geomorphological evidences of the tectonic activity; therefore they are underestimated. Moreover, faults with strike-slip motion, which do not create great relief and/or sediments associated with their tectonic activity, are likely to be assessed as quiet faults (Villamor et al., 2012). Besides, in this area (Iberian Massif) the scarcity of Mesozoic and Cenozoic deposits make it very difficult to study post variscan tectonic activity (Martín-Serrano et al., 1996; Martín-González, 2009; Antón and De Vicente, 2006). For this reason the study of the recent tectonic activity in these areas must be the result of the integration of geological, geomorphological, structural and seismological data.

The studied region corresponds to the Northwestern and Central-Western part of the Iberian Peninsula covering the NW of Spain and the Western Fringe of the Cenozoic Duero Basin (WCB) (Fig.1). In this paper we perform a tectonic and dynamic analysis of the main seismic sequences occurred in the study area (Anton et al. 2012). We analyze the aftershocks series distribution and the focal mechanisms available in relation to the regional stress state, and possible local stress fields, and we try to determine the fault orientations that are potentially active. We also analyzed the morphological record induced by the recent activity of most active faults in the region, and the most appropriate methodologies to interpret that record.

\section{Geological and tectonic setting}

The study area predominantly comprises Precambrian and Paleozoic rocks that form the Iberian Massif (Fig. 1). These rocks were mainly deformed and metamorphosed by the Variscan Orogeny (Upper Devonian-Carboniferous in age), and are intruded by igneous rocks, mainly in the western region, during the Carboniferous and Permian times. In the NW Iberian Peninsula, the overall Variscan structure shows an arch-like shape (Asturian Arch) open to the west, where the inner parts of the Varsican Orogen are located (Martínez-Catalán et al., 1990; Arenas and Martínez-Catalán, 2003).

The most recent structures in the NW Iberian Peninsula are associated with the western termination of the AlpinePyrenean Orogen relief (Pyrenees in the east and the Cantabrian Mountains in the west) (Gallastegui et al., 2002; Muñoz, 2002; Barnolas and Pujalte, 2004; De Vicente 

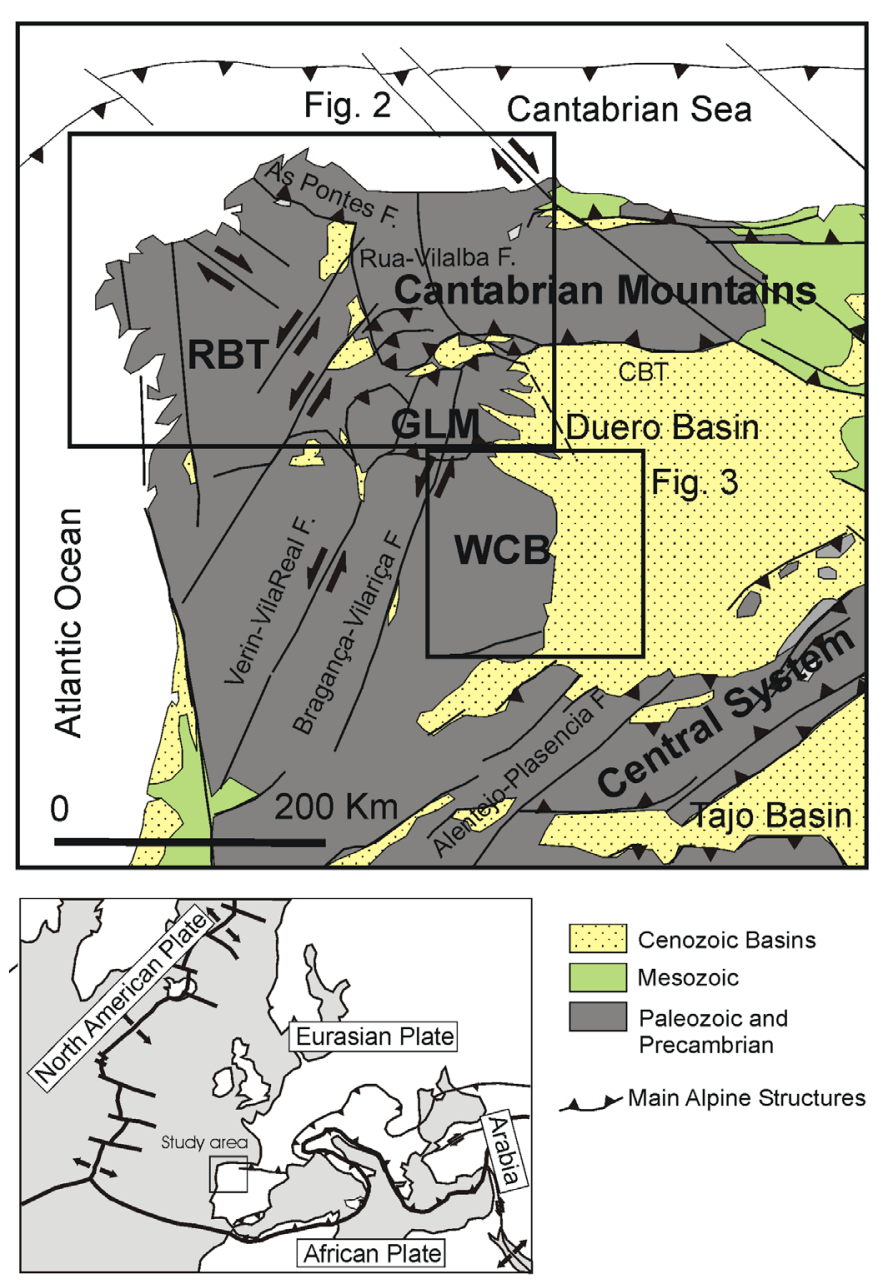

Fig. 1.- Geological sketch with the location of the studied areas. Inset: Location of the study region in the plate tectonic context.

Fig. 1.- Esquema geológico con la localización de las áreas estudiadas. Recuadro: Localización del área de estudio intraplaca en el contexto de las placas tectónicas.

and Vegas, 2009; Martín-González and Heredia, 2011a, b) (Fig. 2). The Pyrenees forms the border between Eurasia and the Iberian Peninsula microplate, trending ESEWNW, and represents a doubly verging continental collision orogen (Choukroune et al., 1990; Muñoz, 1992; Teixell, 1998). The Alpine structures of the Cantabrian Mountains can be divided, based on involved lithologies, age and deformational style, into two regions: the VascoCantabrica (VC) in the E and the Astur-Galaica (AG) in the W (Martín-González and Heredia, 2011b)

In the Astur-Galaica region, the overall Alpine structure is a regional monoclinal flexure that corresponds to the back-limb of a major fault-bend fold related to the Cantabrian Basal Thrust (CBT). This north-dipping basement thrust overturns the Mesozoic-Cenozoic sediments in the south border of the Cantabrian Mountains (Alonso et al., 1996). In the western termination of the CM thrusts there are N-S trending structures (Ibias-Ancares and Rúa-Vilalba structures) (Martín-González and Heredia, 2011a, b) (Fig. 2). These structures partially accommodate the CBT shortening to the north. Therefore, part of the convergence was accommodated by NW-SE faults (Santanach, 1994; Martín-González et al., 2003; Vegas, 2005; De Vicente and Vegas, 2009). These types of movements are also found to the east, in the Ventaniella fault (Cantabrian Mountains) and within the Iberian Chain (e.g. De Vicente and Vegas, 2009; Martín-González and Heredia, 2011b). The compression responsible for these structures is the $\mathrm{N}-\mathrm{S}$ maximum horizontal stress related with the Pyrenean collision. In Central Iberia, the uplift of the Iberian Chain and the Central System produced an intraplate deformation belt that was also related to the Pyrenean collisional processes, and some left lateral strike slip fault corridors were also developed, as the Bragança-Vilariça and VerínVila Real fault corridors or fault systems (Cabral, 1995).

Subsequently, to the south of the CM, the GalaicoLeoneses Mountains (GLM) were emplaced towards the north by north-verging thrusts, causing the erosion of the early foreland basin (western Duero Basin) located in front of the Cantabrian Mountains (Fig. 1). Shortening of the GLM north-verging thrusts was accommodated by NNE-SSW strike-slip faults (e.g. Bragança-Vilariça and Verín-Vila Real corridors), this took place mainly during the Late Miocene and therefore related with the Betic collision (Martín-González et al., 2011). In contrast, the Rias Baixas-Terra Cha Region (RBT) represents the less deformed region of the foreland (Martín-González and Heredia, 2011b) (Fig. 1). Neotectonic activity has been described in the NW Iberian Peninsula related with faulted fluvial deposits and deformed marine terraces (Martínez-Graña et al., 2000; Rodríguez García et al., 2006; Gutiérrez Claverol et al., 2006). Also, complex systems of captures and inversion of the drainage network in Tambre and Xallas rivers (Western Galicia) have been described (Pagés and Vidal Romaní, 1997), as well as drainage diversion related to fault activity in El Caurel Mountains (Martín-González, 2009).

To the South and easternmost of the Bragança-Vilariça corridor, is located the region of the Western Fringe of the Cenozoic Duero Basin (WCB) (Figs. 1 and 3). This region is characterized by vast outcrops of uplifted variscan basement. The WCB area consists of uplifted blocks of Precambrian and Paleozoic metamorphic rocks and Pre-Variscan and Variscan granitic rocks within a tectonically complex zone that was intensely deformed during the Variscan Orogeny (Diez Balda et al., 1990).

The WCB region shows a clear fault pattern, with a dominant NNE-SSW trend (e.g. Duero, Almendra, Almeida-Valderaduey faults) (Antón et al., 2010a), which is consistent with the large, neotectonically-active fault systems to the west (Bragança-Vilariça corridor) (Cabral, 


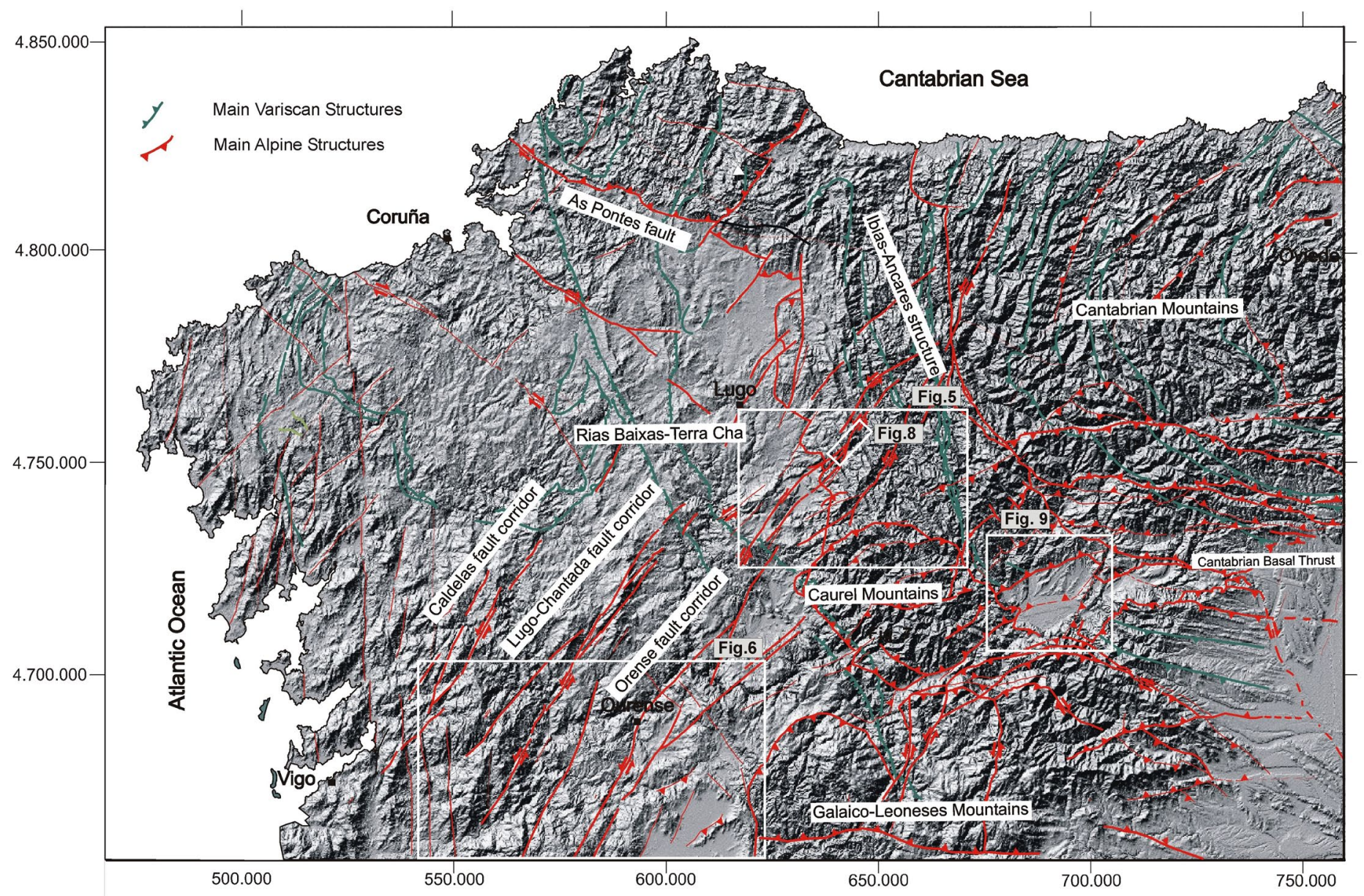

Fig. 2.- Digital elevation model with the main Alpine structures in NW Iberian Peninsula.

Fig. 2.- Modelo digital de elevación con las principales estructuras del NO de la Península Ibérica.

1989; Cabral and Ribeiro, 1993; Rockwell et al., 2009; Cabral et al., 2010) (Fig. 1) and, although there is plenty of petrologic and structural information about the zone (e.g. Arthaud and Matte, 1975; 1977; Diez Balda et al., 1992; Iglesias Ponce de Leon and Choukroune, 1980; López-Plaza and Gonzalo, 1986; Martínez-Fernández, 1974a; Martínez-Fernández, 1974b; Martínez, 1977) little has been published about the tectonic evolution of these faults during the Mesozoic and the Cenozoic.

Addressing this issue, previous studies (Antón, 2004; Antón et al. 2010a) based on stress inversion methods from population of faults, revealed the presence in the WCB area of three dominant maximum horizontal stress (Shmax) trends, which were active from Triassic to present day: E-W, NE-SW and N-S. Relative and absolute dating of the activated faults supported the idea that the N-S compression was active from the Middle Paleogene to the Pleistocene, while a NE-SW stress field is found to have been active during the Cretaceous and an older $\mathrm{E}-\mathrm{W}$ paleostress field was active in the earlier Alpine cycle (Late Triassic) (Antón et al. 2010a). Instrumental seismicity in this area indicates a local N-S oriented of Shmax (Antón et al., 2010a), while regional data show a more NW-SE oriented Shmax (De Vicente et al., 2008).

The whole study area was deformed by extensional and strike-slip brittle faulting during post-Variscan and Alpine times (Arthaud and Matte, 1975; Vegas, 2005; MartínGonzález et al. 2011). This last brittle deformation was related to the opening of the atlantic margin in western Iberia during the Triassic and Jurassic (Srivastava et al., 1990) and the far-field effects of the Alpine and current tectonic history of Iberia: convergence at the northern and southern borders (Pyrenees and Betics) (Andeweg et al., 1999; Galindo-Zaldivar et al., 1993; Galindo-Zaldivar et al., 1999; Liesa and Simon, 2009).

\section{Seismicity}

The analysis of seismic catalogues revealed that in the study area a moderate seismicity occurs. The National Seismic Catalogue, managed by the Instituto Geográfico Nacional (IGN), contains 4,380 historic and instrumental 
events in NW Iberian Peninsula (Fig. 4) since the year 1347 until $27^{\text {th }}$ august 2011 . The seismic events registered in the study region represent the $8.5 \%$ of the total events in the Iberian Peninsula.

In terms of depth and magnitude, $94 \%$ of the earthquakes have magnitude value determined and only $56 \%$ have hypocentral solution. $97 \%$ of the seismicity occurs in the upper crust, with hypocenter depths lower than 15 km. (Fig. 4). 90\% of the earthquakes have magnitudes lower than $3.5 \mathrm{mb}$.

\subsection{Lugo seismic sequences (Sarria-Triacastela-Becerreá)}

The recent seismicity recorded is mainly located in SW of Galicia, in Lugo (1995 and 1997, Lugo sequences, 5.1 $\mathrm{mb}$ ), south of the Cenozoic depression of Sarria. At this area, NNW vergent thrusts joint NE-SW strike-slip fault corridor (Martínez-Díaz et al., 2006; Martín-González et al., 2006) (Fig. 2).

Seismic activity in the area of Sarria-Triacastela-Becerreá began in 1995 with two earthquakes of magnitude 4.6 $\mathrm{mb}$ (November 29 and December 24, 1995) and their associated aftershocks. In May 1997 a second series followed the former, begining with an earthquake of magnitude 5.1 $\mathrm{mb}$ (http://www.ign.es/ign/es/IGN/SisCatalogo.jsp).

The 1995 sequence was composed by two subseries. The first one began with a $4.6 \mathrm{mb}$ earthquake on November 29th, 1995, followed by a series of aftershocks, up to 37 during the same day. Their frequency decreased rapidly in 20 days, following the Omori law (Martínez-Díaz et al., 2006). The second subseries began with another 4.6 $\mathrm{mb}$ earthquake on 24th December of that year and was followed by a series of aftershocks of lesser importance. In 1996 and part of 1997 the recorded events did not exceed the magnitude $4.1 \mathrm{mb}$. In the 21th May, 1997 a 5.1 $\mathrm{mb}$ earthquake started the second seismic sequence. This earthquake was preceded by a premonitory of magnitude $4.2 \mathrm{mb}$, only 59 seconds before the main event. After that, a large series of 106 aftershocks took place in 24 hours, one of which reached magnitude $4.5 \mathrm{mb}$. The sequence of aftershocks decayed according to the Omori law within the thirty following days.

The 1997 sequence has a significant southeastward migration in relation to the 1995 sequence. Moreover, the position of the epicenters of the major earthquakes and the temporal sequence of the events has been interpreted as triggering mechanisms between the main events (Martínez-Díaz et al., 2006).

From 1994 to 2005, 25 focal mechanisms have been calculated in the Lugo area (Herraiz et al., 1998; Rueda and Mezcua, 2001; Harvard, 2001; Pondrelli et al., 2002; Stich et al., 2003; López et al., 2004b). Only fifteen be- long strictly to the seismic crisis of 1995 (Herraiz et al., 1998; Rueda and Mezcua, 2001) and 1997 (Herraiz et al., 1998; Rueda and Mezcua, 2001; Harvard, 2001; Pondrelli et al., 2002; Stich et al., 2003), all of them summarized in Fig. 5. In this figure, are also displayed twelve focal mechanisms calculated by the IGN (institute responsible for the Spanish Seismic Network) (Rueda and Mezcua, 2001), three mechanisms from the SIGMA project (Herraiz et al., 2000) of the three largest events of the 1995 sequence, two mechanisms of the biggest events of the 1997 sequence calculated by Harvard CMT Project, one mechanism of the 1997 series calculated by Pondrelli et al. (2002), and two mechanisms form Stich et al. (2003). The later five focal mechanisms were calculated by the Centroid Moment Tensor method (CMT). There are also other focal mechanisms solutions from the same area recorded from 1999 to 2002, offering us valuable information about the active faults in the area (Lopez et al., 2004a and 2004b).

There are important differences between the published focal mechanisms solutions. For example, the first event of the second series (1997) has a reverse type solutions following the data from Rueda and Mezcua (2001), while other authors propose extensional type solutions (Stich et al., 2003). The same discrepancy exists between the mechanisms calculated for the first 4.6 magnitude event in the 1995 series (Fig. 5) (Herraiz et al., 2000, Rueda and Mezcua, 2001). It is not the scope of this work to discriminate or asses which is the best published solution. Therefore an analysis with all the solutions has been made. The published solutions can be gather in two groups, solutions indicating left-lateral strike slip faulting with reverse component trending NE-SW to NNE-SSW, and solution indicating normal faults trending NW-SE. The focal mechanisms calculated with a more accurate seismic network installed after the seismic sequences of Lugo (Lopez et al., 2004a and 2004b) are in agreement with strike-slip faulting with reverse component.

Despite the different focal mechanism solution published, the maximum horizontal compressive stress for the region is consistent in all of them. With all the focal mechanism of the Lugo seismic sequence, a NW-SE shortening is observed (Martín-González, 2005). Using a larger number of focal mechanisms including the whole Northwest Iberian Peninsula, González-Casado and Giner (2000) obtained the same NW-SE direction, which is in turn the same solution of Rueda and Mezcua (2001).

The analysis of the spatial distribution of hypocenters shows that they apparently define a plane striking NNESSW with a dip of $\sim 80^{\circ}$ towards the SE, extending to a depth around $15 \mathrm{~km}$. In the second crisis, the pattern of distribution does not appear so clear and its dispersion is 


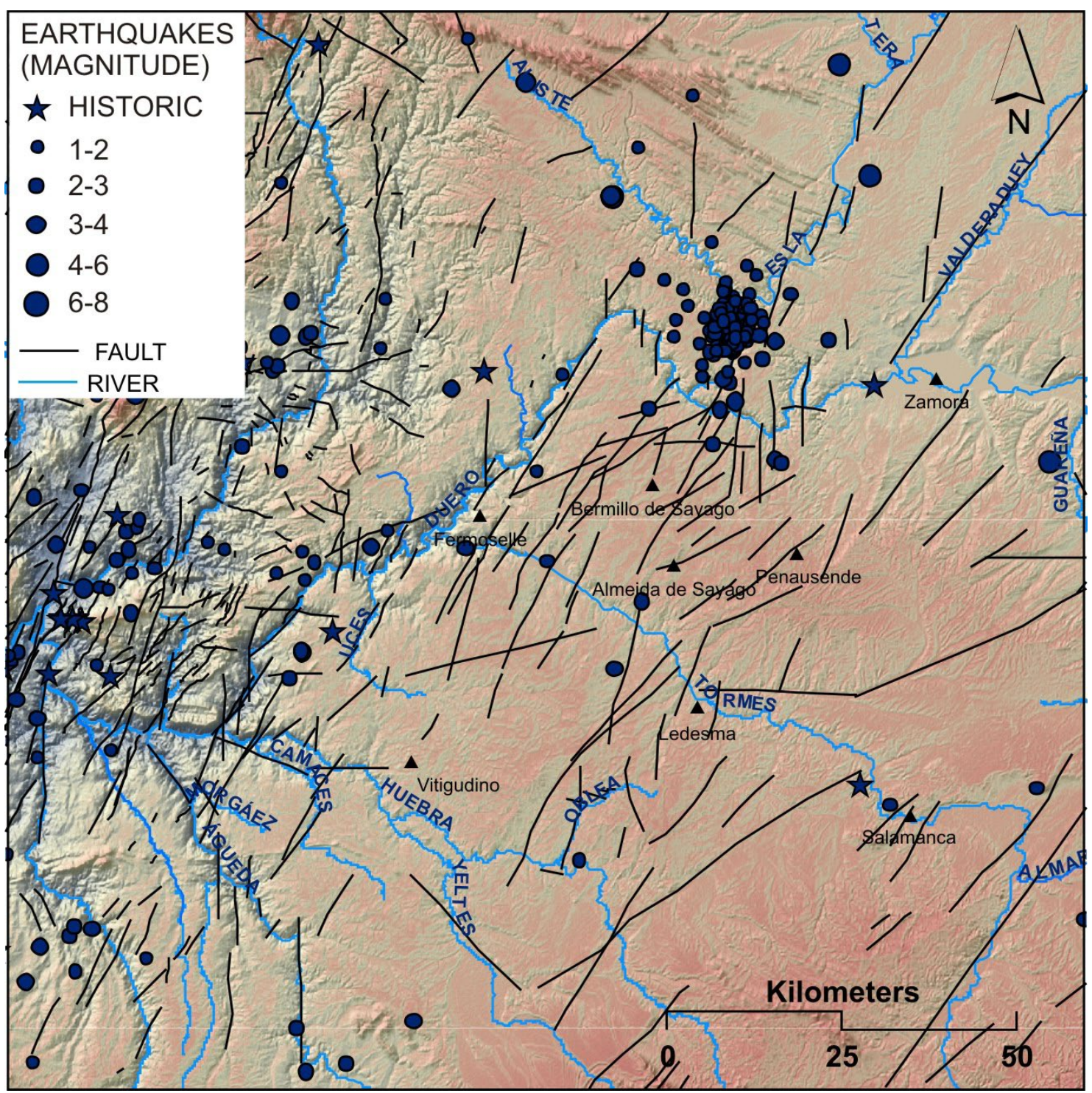

Fig. 3.- Western Fringe of the Cenozoic Duero Basin area (Central-West Iberian Peninsula), earthquake epicenters and main faults. DEM SRTM4 (Jarvis et al., 2008). Projection UTM30. Location in Fig. 2.

Fig. 3.- Borde Oeste de la Cuenca Cenozoica del Duero. Se muestran los epicentros y las principales fallas. DEM SRTM4 (Jarvis et al., 2008). UTM30. Localización en Fig. 2.

much larger, but there is a clear spatial migration of hypocenters, indicating a reactivation of several faults located further southeast of the first (Martínez-Díaz et al., 2006).

Despite the significant contradictions between the focal mechanisms calculated for the area there are some common aspects. In the first series, the focal mechanisms identified by different authors indicate the existence of a common nodal plane with minimum differences, oriented NNE, with left lateral movement. Focal mechanisms of the second series, one of the nodal planes is again similar to that observed in the first series. Although, in this case, the strike slip component is lower (Fig. 5).

Looking at the structures mapped in the area (Figs. 3 and 5), the faults that better fit the mechanisms solutions could be grouped as follows:

1.-The NE-SW strike slip faults with some reverse component (Vilachá, Ferreiros, Baralla, Becerreá, Loseiro and Loureiro faults).

2.-The youngest NE-SW thrust of the Caurel Mountains (Villaesteva thrust)

Focal Mechanisms calculated after the seismic crisis indicates the existence of a great variety of solutions, which apparently indicate a readjustment of many structures. In general, the 1997 seismic crisis has been identified as triggered by the first series on 1995. This triggering effect is only justifiable if the fault of the first sequence is a NESW left lateral strike-slip fault with reverse component (Martínez-Díaz et al., 2006). 

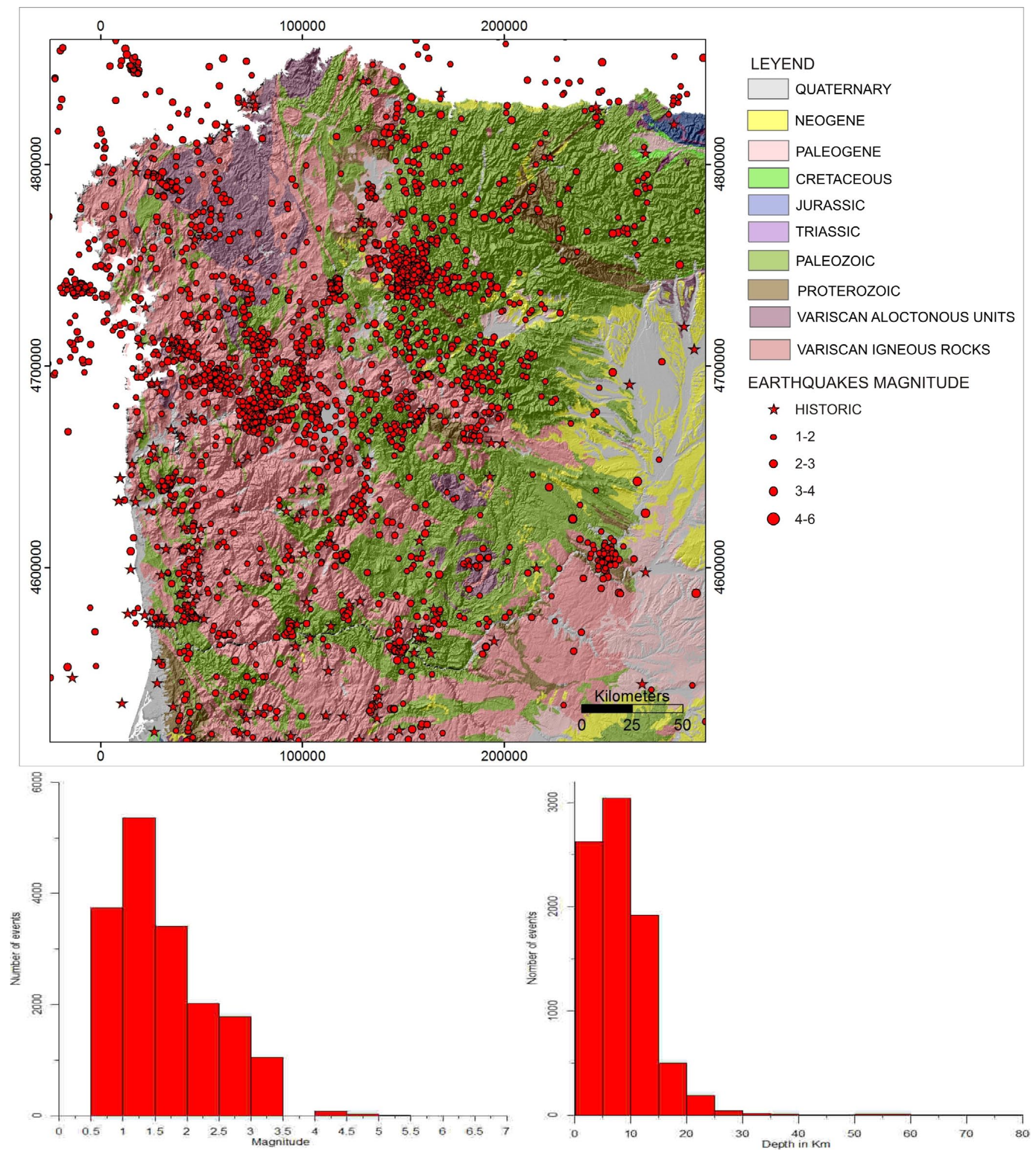

Fig. 4.- NW Iberian Peninsula geological map (modified from IGME 1:1,000,000) and distribution of earthquakes epicenters (1347-2011). Projection UTM30.

Fig. 4.- Mapa geológico del NW de la Península Ibérica (modificado de IGME 1:1.000.000) con la distribución de terremotos (1347-2011). UTM 30.

\subsection{Orense seismic sequences (Celanova)}

Since the 90's a significant seismicity has been recorded in the Orense region. Events reach a magnitude of $3.8 \mathrm{mb}$ and the years with seismicity particularly intense were 1998, with 96 events (maximum magnitude of $3.6 \mathrm{mb}$ ), and 2005, with 108 events (maximum magnitude of 2.8 $\mathrm{mb}$ ). The most notable increase in the number of events 

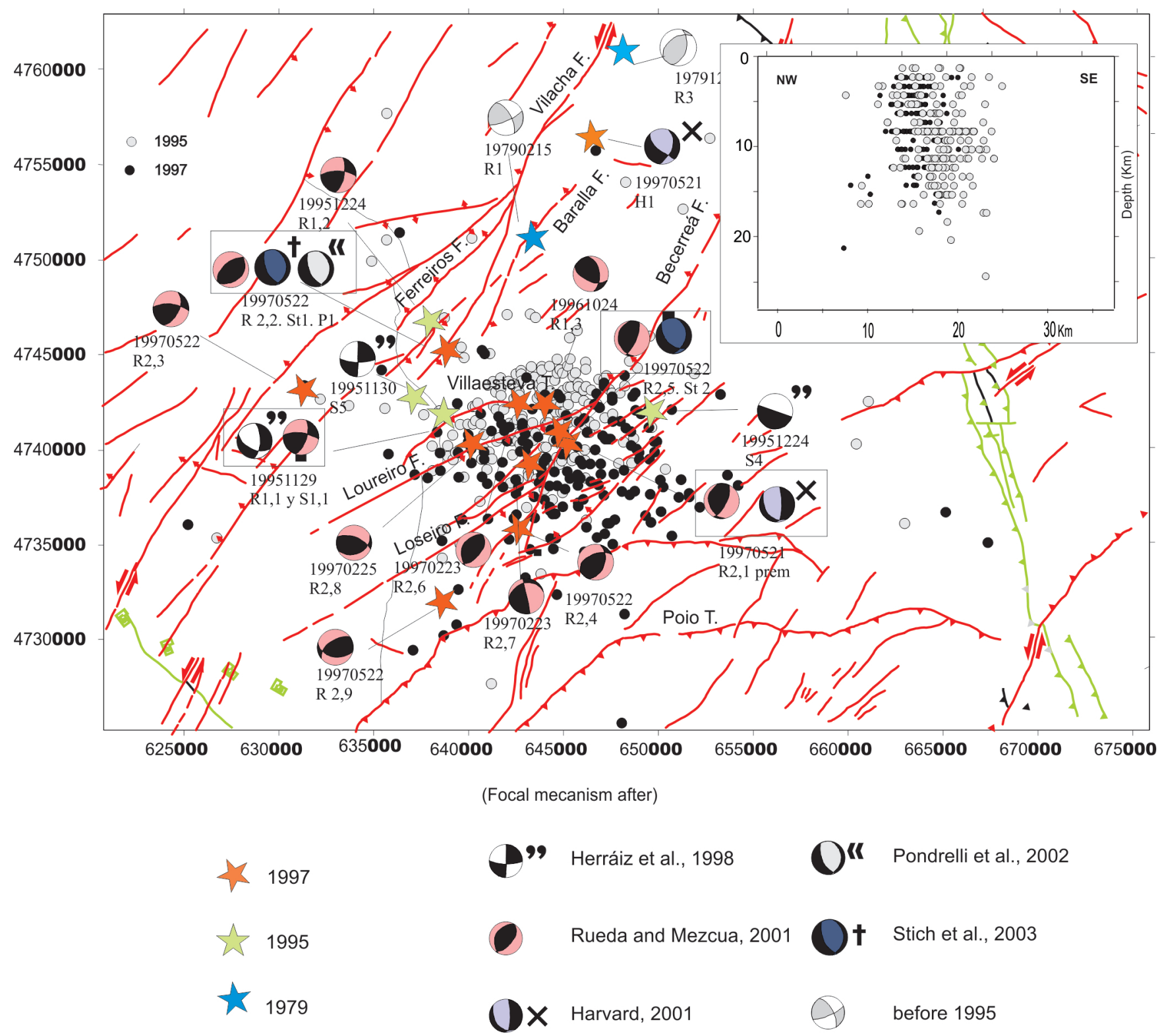

Fig. 5.- Compilation of the focal mechanisms in the Sarria-Triacastela-Becerreá(Lugo seismic sequences) region overlain the tectonic map. Inset shows a NW-SE cross section of the events of the two seismic sequences in 1995 and 1996 showing a NE-SW orientation dipping SE. Green faults are Variscan in age, red faults are Alpine in age. Location in Fig. 2.

Fig. 5.- Recopilación de los mecanismos focales en la región de Sarria-Triacastela-Becerreá (Crisis de Lugo, Sierra de El Caurel), donde se superpone el mapa tectónico. El recuadro muestra los terremotos de las dos crisis de 1995 y 1997 en un corte NO-SE mostrando una orientación NE-SO con buzamiento hacia el SE. Las fallas verdes son Variscas y las rojas son Alpinas. Localización en Fig. 2.

occurs after the crisis of Lugo in 1997. Seismicity can be grouped in three zones. Although there has been an event at a depth of $33 \mathrm{~km}$, maximum depth does not exceed 26 $\mathrm{km}$ and is concentrated around $7 \mathrm{~km}$ (Fig. 6).

In the 1980-1990 decade, earthquakes were scarce and they were concentrated around the basin of Xinzo de Limia (Sandias) (Fig. 6). In the 1990-2000 decade seismicity started west of Celanova with a NNE-SSW trending distribution. In the 2000-2010 decade the magnitude of the events decreased but the number increased. The seismicity in Celanova continues, trending NNE-SSW, and another crisis started east of Mondariz. Broadly speaking, seismicity seems to migrate towards SW. In depth events seem to fit a NNE-SSW trending plane strongly dipping to SE (Fig. 6).

The distribution of epicenters (Fig. 6) and hypocenters (section WNW-ESE, b-b' in Fig. 6) seems to be orientated in NE-SW planes. They fit with the main faults which are NE-SW strike-slip faults (Fig. 6). Regionally they correspond to the Orense and Lugo-Chantada fault corridors (Fig. 2 and 6). Northward, the Orense fault corridor links with the faults that are the responsible for the 
Sarria-Triacastela-Becerrea seismicity (Figs. 2, 5). The connection of the structures in a NE-SW fault corridor, and the temporal migration of the seismicity can be interpreted as the southwest migration of the activity following these NE-SW corridors (Fig. 6).

\subsection{The western fringe of the Cenozoic Duero Basin and the "Muelas del Pan" seismic sequences.}

Data compilation of instrumental seismic activity for the WCB (http://www.ign.es/ign/es/IGN/SisCatalogo. jsp; Stich et al., 2003) provides important information in relation to the moderate active deformation of this intraplate area and the currently active tectonic stresses.

The IGN catalog contains 189 earthquakes registered in the WCB area, since the year 1831 to August 2011, corresponding magnitudes ranging from 0.8 to $5.2 \mathrm{mb}$ (Fig. 3). The majority of the events are in the depth range from 1 to $15 \mathrm{~km}$, which is characteristic of brittle deformation in the upper crust of continental intraplate areas. Only 10 events are in the depth range from 15 to 23 $\mathrm{km}$. The location of most of the registered events have a RMS value lower than 0.75 .

The maximum magnitude seismic events (5.2 MD, Mezcua y Martínez Solares, 1983) correspond to earthquakes that occurred close to in Zamora in 1961. The spatial distribution of epicenters shows an important cluster in the Muelas del Pan-Villalcampo area, where 114 earthquakes have been recorded since 1995. In this area, two seismic sequences with events magnitudes higher than 3.4, occurred in 2001 and 2003 (Fig. 7). The distribution of the events of the seismic sequence could be related the Esla fault. This fault is a NNE-SSW trending segment where the Esla River is deeply incised (Antón et al. 2011). In this region NNE-SSW lineations are wide recognized (Figs. 3 and 7)

The largest sequence was recorded in 2003 and started with a $3.8 \mathrm{Mw}$ event in January $12^{\text {th }} 2003$, followed by 15 aftershocks in 2 days. On January $23^{\text {th }} 2003$, another event of $4.2 \mathrm{Mw}$ occurred and was followed by 7 aftershocks in the next 2 days. On January and February 2003, 58 seismic events occurred in this area (Fig. 7).

The two main earthquakes occurred in January 2003, with magnitudes (Mw) 3.8 and 4.2 respectively. It was possible to determine well-constrained focal mechanisms from moment tensor solutions (Stich et al., 2003) (Fig. 7). These are typical strike-slip faulting solutions with a NNE-SSW trending $\left(\mathrm{N}^{\circ}-12^{\circ} \mathrm{E}\right)$ nodal plane (Antón, 2004; Antón and De Vicente, 2006; Antón et al., 2010a). These focal mechanisms seem to indicate that the Esla fault system, with an average $\mathrm{N} 10^{\circ} \mathrm{E}$ trend, is moving as a left lateral strike slip structure under the present regional N-S to NW-SE compression (Antón et al., 2010b). From this evidence, NNE-SSW faults located to the west, like those from the Bragança-Vilariça, Verin-Vila Real and Orense fault corridors, should also be moving as left-lateral strike-slip faults with some reverse component.

\section{Geomorfological evidences of recent tectonic activity}

Throughout the entire study area several geomorphological evidences of the presence of recent tectonic activity have been recognized, as exemplified bellow:

\subsection{NE-SW trending strike-slip faults in Galicia}

NE-SW strike-slip faults are potentially active in the NW Iberian Peninsula. A representative fault of those is the Ferreiros fault, which has been studied in detail. We may evaluate the fault kinematics after the establishment of the regional drainage network. The Ferreiros fault is a left lateral strike-slip fault with a horizontal offset of 800 $\mathrm{m}$ on Variscan markers. This fault belongs to the fault system that limits the Cenozoic deposits of the Sarria depression (Fig. 2). Ferreiros fault diverts channels with NW-SE trend. There are four main channels that are deflecting when crossing the fault. More than fifteen channels can be identified in the south block (downstream) but only four of these channels can be continued upstream and the rest are beheaded streams. Moreover, ridges that divide the channels became offset by Ferreiros fault (Fig. 8).

The whole displacement of the Ferreiros fault has been balanced in order to know whether all the displacement has occurred when the drainage network was established. After removing the offsets of the Variscan marker the drainage fits again. Therefore, the fault horizontal displacement has occurred after the drainage was established. Unfortunately no data about drainage ages are available to estimate slip rates.

\subsection{El Bierzo depressions}

El Bierzo Cenozoic depressions are filled with detritic and carbonated sediments which are in turn, deformed by E-W and ESE-WNW thrusts (Fig. 9). The largest basin is the Ponferrada basin, which is drained by the Sil river which flows from NE to SW and is deflected towards the west in the southern limit of the basin. The main channel has terraces exclusively on its right bank (Fig. 9), 


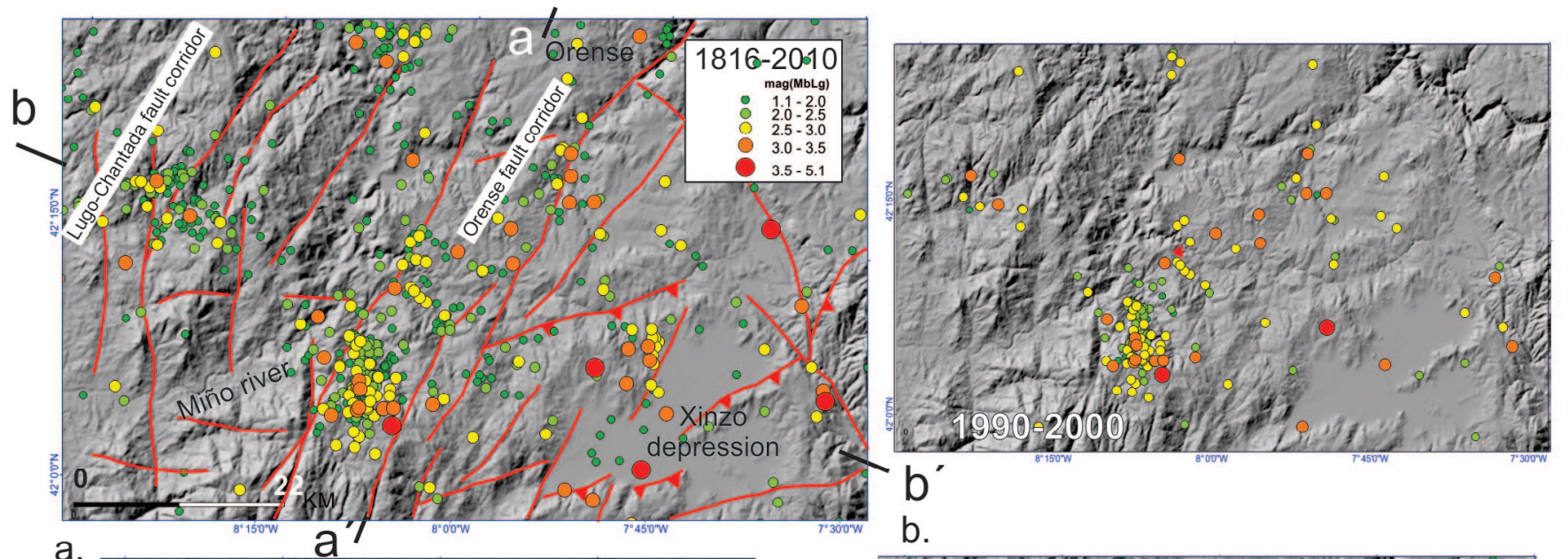

a.

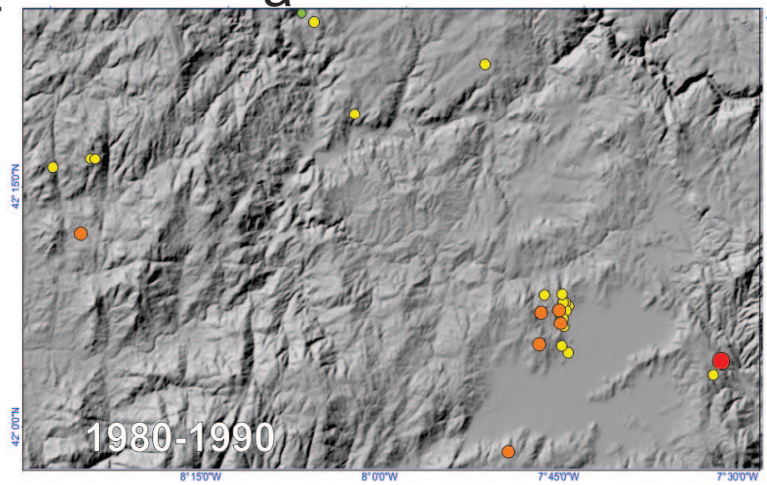

C.

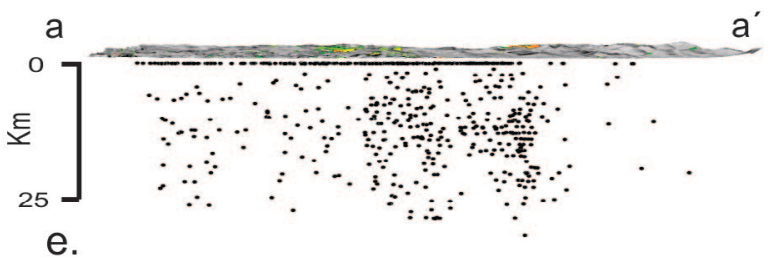

$a^{\prime}$
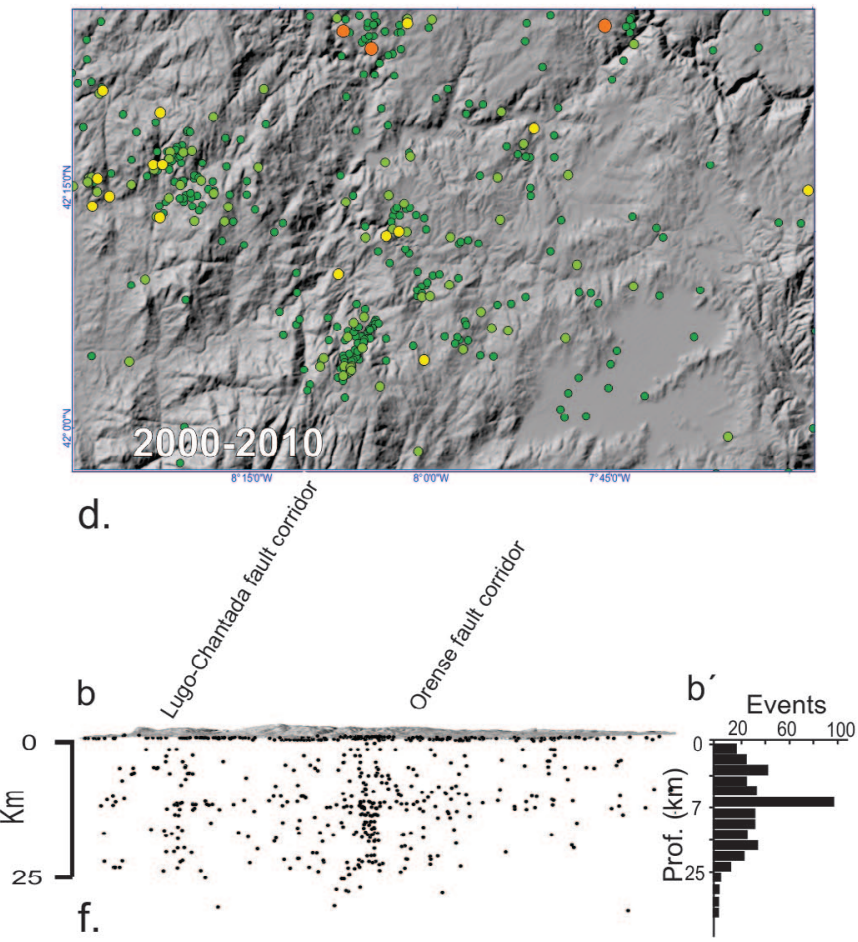

Fig. 6.- (a) Digital elevation model of the Orense region, showing the seismic events in the area and the neotectoic structures. Seismic events are grouped by decades: (b) 1980-1990.; (c) 1990-2000; (d) 2000-2010. (e) a-a'and (f) b-b' are cross sections showing the hypocenters orientation and the trend of the possible fault planes. Location in Fig. 2.

Fig. 6.- (a) Modelo digital de elevación de la región de Orense donde se muestran los terremotos y las estructuras tectónicas. Los terremotos están agrupados por décadas (b) 1980-1990; (c) 1990-2000; (d) 2000-2010. (e) a-a’ y (f) b-b’ son cortes mostrando la orientación de los hipocentros y la orientación de las posibles fallas. Localización en Fig. 2.

and on the northern side of the basin the drainage pattern develops a parallel pattern flowing towards the SSW and shows a relevant asymmetry, depicting that the main channel is displaced southwards.

Topographic profiles have been executed across the basin. They show that the depression has a gentle slope towards the south and presents terraces only in the right (north) bank of the main channel, evidencing a southwards tilting of the basin. This tilting can be explained by the effect of the north vergent thrusts that limit the depression on its southern side and uplift the Aquilianos and Teleno Mountains $(2100 \mathrm{~m})$ which are younger than the south vergent thrust (Martín-González et al., 2011) (Fig. 9)

\subsection{The Western Fringe of the Cenozoic Duero Basin}

In the WCB, systematic analysis of structures affecting the Cenozoic sediments shows how they are coincident with fault trends related to the present stress field (Antón, 

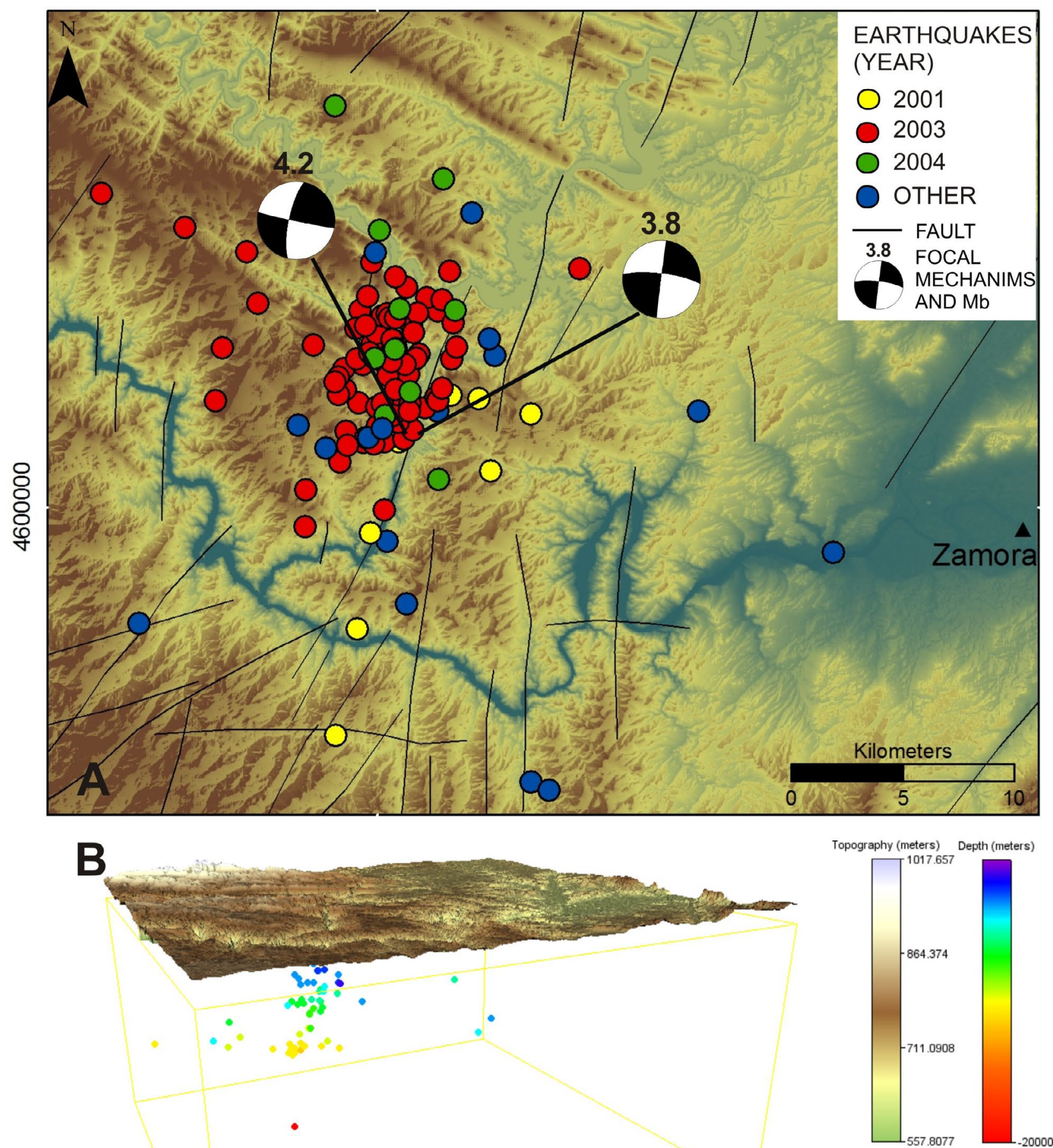

Fig. 7.- Esla fault area, seismicity and focal mechanisms. Epicenter distribution and hypocenters location showing a possible fault plane orientation. Location in Fig. 2.

Fig. 7.- Zona de la Falla del Esla, sismicidad y mecanismos focales. Distribución de epicentros y localización de hipocentros, que muestran las posible orientación del plano de falla. Localización en Fig. 2. 
Fig. 8.- The Ferreiros strike-slip fault with the main geomorphological features. (DEM 25 metres resolution). Note the channel deflection and beheaded channels caused by the southeaster block displacement. Strike-slip displacement has been reconstructed from present to 800m (modified from Martin-Gonzalez, 2009). Location in Fig. 2.

Fig. 8.- La falla de desgarre de Ferreiros con los principales aspectos geomorfológicos (MDT de $25 \mathrm{~m}$ de resolución). Nótese los giros y los canales decapitados causados por el desplazamiento del bloque sur. El desplazamiento de desgarre ha sido restaurado desde la posición actual hasta los $800 \mathrm{~m}$ (modificado de MartinGonzález, 2009). Localización en Fig. 2.
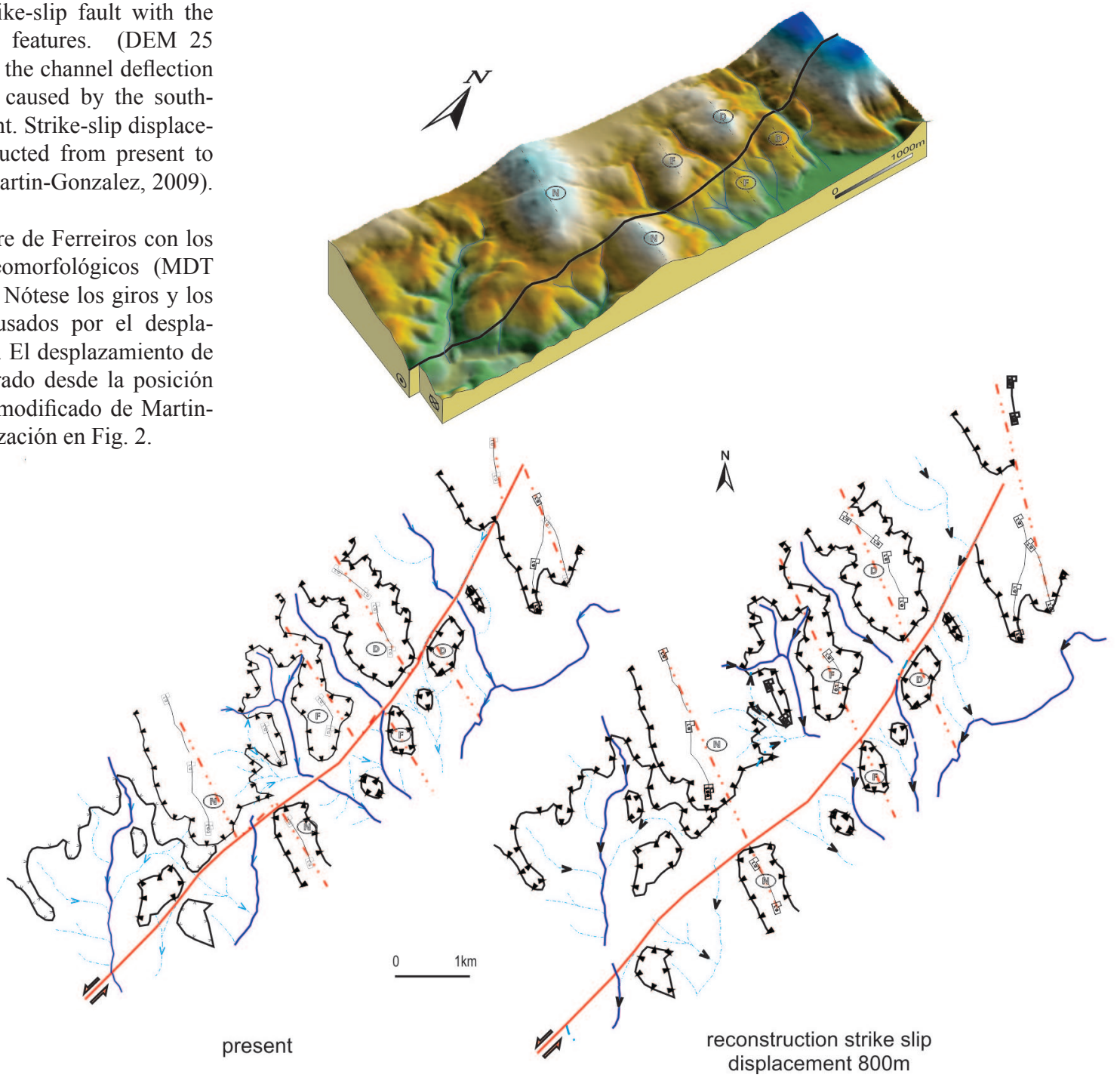

2004). Faults mostly trending N-S to NE-SW are dissecting Cenozoic deposits and inducing vertical displacement, sinking westwards (Villar-Alonso et al., 2000).

An important neotectonic feature within the WCB is the asymmetry in the fluvial deposits distribution, common to most of the N-S and NW-SE trending streams (Fig. 10 a, b and c). Lateral migration of fluvial deposits give place to asymmetric valleys showing gentle western and southwestern slopes, where glacis deposits are present, with opposite steeper margins. Some examples occur in the northeastern part of the area, where NW-SE, $\mathrm{N}-\mathrm{S}$ and E-W streams (Fig. 9b) show deposits restricted to the western and southern margins, respectively. Southernmost of the Oblea river (Fig. 10b) a N-S structure is conditioning the fluvial asymmetry, with sediments only present in the western margin. Asymmetry in Quaternary fluvial deposits and lateral migration of valleys seems to be related with an E-W to ENE-WSW extension (Antón, 2004) resulting in block tilting to the east, also described by other authors (Escuder et al., 2000; Santisteban et al., 1996). This process is mostly conditioned by N-S to NWSE trending faults (Fig. 10e).

Other field observations, such as faults with a clear Cenozoic activity, e.g. Golpejas fault (Fig. 10d) among others, support the presence of a transpressive shear zone, formed by two conjugate faults systems trending $\sim \mathrm{N} 30^{\circ} \mathrm{E}$ and $\sim \mathrm{N} 140^{\circ} \mathrm{E}$, that conditioned the contact between Paleozoic metamorphic rocks and lower Eocene sediments (Santisteban and Martín-Serrano, 1991).

\section{Potentially active faults}

The seismic activity recorded during the historical and instrumental periods in the study region can be considered moderate; although it is noteworthy that in 1997 was recorded in Lugo one of the largest magnitude earthquake $(5.1 \mathrm{mb})$ occurred in the instrumental period of the Iberian Peninsula. The epicentral locations show a scattered 
distribution but with some clusters associated with larger seismic sequences (Fig. 4). The spatial distribution of seismicity concentrates on lineaments that match with neotectonic faults trending NE-SW. The seismicity seems to migrate southward following these trends as evidenced by the seismicity increase in Orense after the seismic crisis of Lugo.

The distribution of seismicity at depth (see histogram in Fig. 4) indicates that over $80 \%$ of the seismicity is concentrated in the upper $25 \mathrm{~km}$ of crust. This is consistent with a rheology controlled by the mechanical nature of an intraplate crust (highly rigid). This behavior combinated with the highly fracturated Variscan basement has been argued to explain some seismic sequences as triggered seismicity by the stress transfer mechanisms, in which earthquakes can trigger another of similar magnitude on faults located nearby.

In this study, we define potentially active faults as faults that can move under the "current tectonic regime" (MuirWood and Mallard, 1992). The current tectonic regime is the period in which the tectonic stresses have remained constant, for the Northwest and Central Iberian Peninsula we will consider that the current tectonic regime starts at least in the Middle Miocene (Srivastava et al., 1990; Andeweg, 2002).

Taking into account that the horizontal maximum compression calculated in the NW Iberian Peninsula is NW-SE (Srivastava et al., 1990; Andeweg 2002), the best orientated structures (among those recognized in the region) that have significant activity are: 1 .-The NE-SW strike-slip faults with a reverse component (as hypocenters distribution, field observation and focal mechanism solutions indicate). 2.-The younger NE-SW thrusts of the Caurel Mountains and the Galaico-Leoneses Mountains (as field observation and some focal mechanism solutions indicate) 3.- The NW-SE normal faults (as some focal mechanism solutions indicate) (Fig. 2). Those groups of structures can be potentially seismogenic faults (Fig. 11). However, the two first groups explain better the seismic sequences analyzed formerly and they agree with the previous sismotectonic studies (González-Casado and Giner, 2000; Rueda y Mezcua, 2001; López et al., 2004a; Martín-González et al., 2006; Martínez-Díaz et al., 2006) that pointed out NE-SW fault moving with a strike-slip movement with reverse component, as the seismogenic faults. Moreover, the strike-slip faults are conspicuous in the region, and long corridors are present running NE$\mathrm{SW}$, supporting the thesis that these corridors are the most probable seismogenics faults in the region. Theses faults are grouped in three main corridors or fault systems: Orense, Lugo-Chantada y Caldelas (Fig. 2). The main seismic sequences (Lugo and Orense sequences)
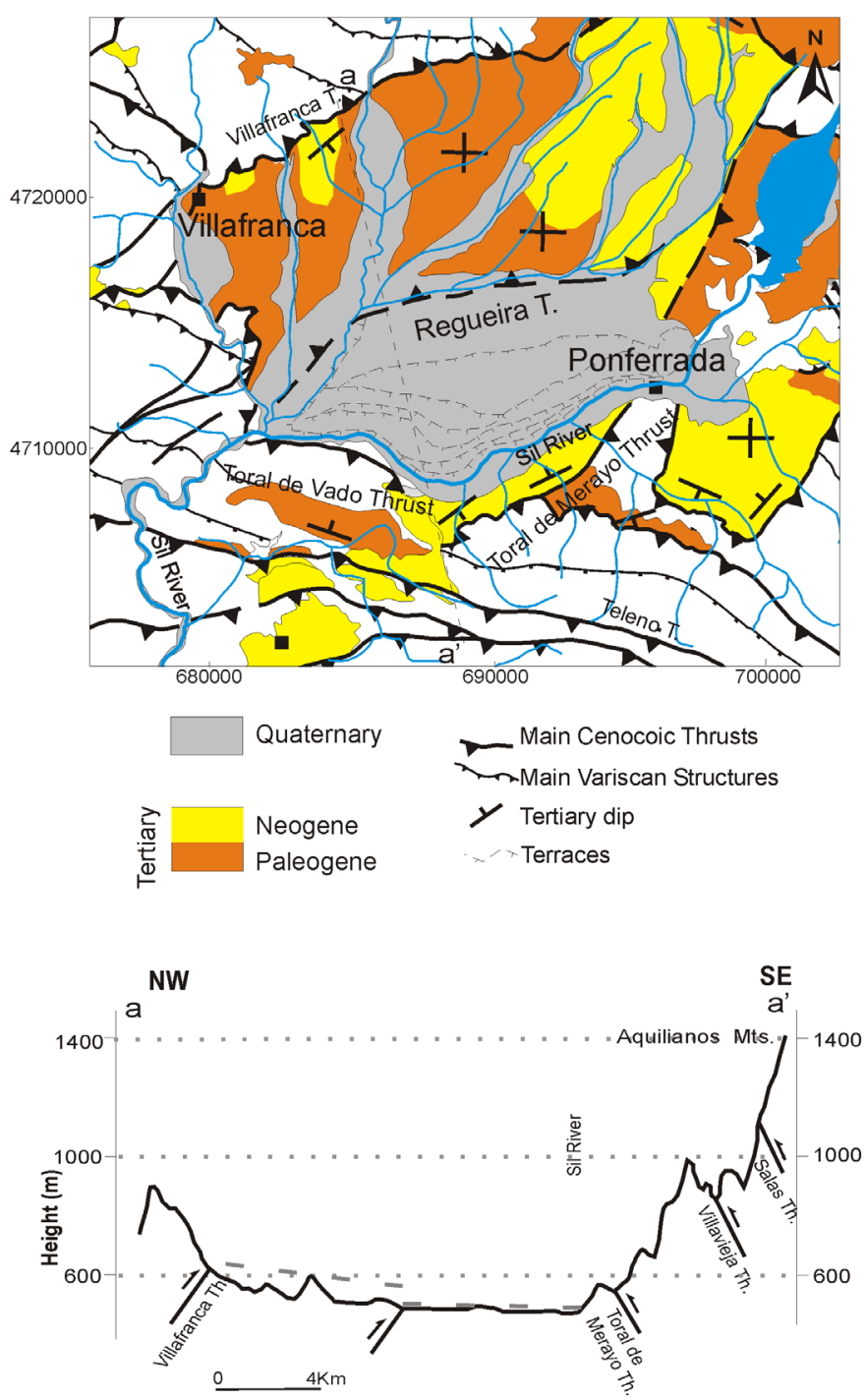

Fig. 9.- Geological map of the Ponferrada (El Bierzo Depression), including the drainage network of the area. This network shows the asymmetry of the drainage patterns and the lack of terraces in the left bank of the Sil River. See Fig. 2 for location.

Fig. 9.- Mapa geológico de Ponferrada (Depresión del Bierzo) al que se ha superpuesto la red de drenaje que muestra una asimetría de la red y la ausencia de terrazas en el margen izquierdo del rio Sil. Localización en Fig. 2.

are related to faults belonging to the Orense corridor. These corridors penetrate in Portugal and have the same orientation as the Bragança-Vilariça fault corridor, which has a slip rate of 0.2-0.5 mm/a (Cabral, 1989 and 1995; Rockwell et al., 2009; Cabral et al., 2010), the Verin-Vila Real fault corridor, and some segments of the AlentejoPlasencia fault (Villamor, 2002) (Figs. 11 and 2).

To the South, the WCB has relatively flat relief at a mean elevation of $750 \mathrm{~m}$ above sea level, but is affected by large-scale fractures dominated by N-S to NNE-SSW left-lateral strike-slip faults (Antón et al., 2010a). However, the relevance of the fracture pattern in the WCB is highlighted, among others, by the fluvial network dis- 


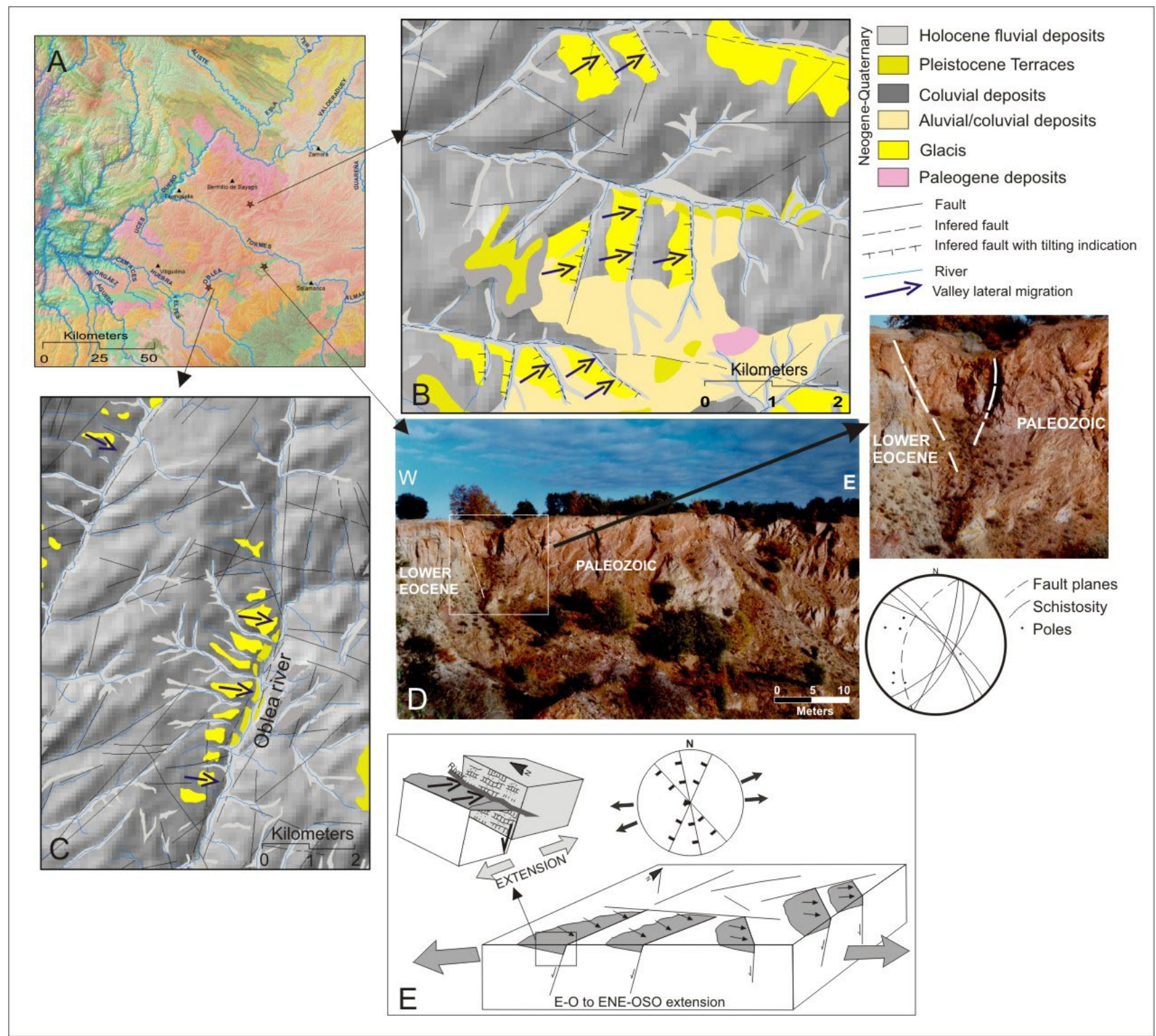

Fig. 10.- Neotectonic evidences in the Western Fringe of the Cenozoic Duero Basin area (DEM SRTM4, Jarvis et al., 2008) A) Location map; B and C) Map showing asymmetric deposit distribution and fluvial migration; D) Picture of the Variscan metamorphic rocks and Cenozoic deposit contact at the Golpejas fault and stereoplot illustrating the relationships between fault geometry, kinematics and schistosity. E) 3D sketch of fluvial migration, structures involved and compatible stress orientation with a NNW-SSE to N-S trending maximum horizontal compression and E-W to ENE-WSW extension.

Fig. 10.- Evidencias de actividad neotectónica en la Borde Oeste de la Cuenca Cenozoica del Duero (MDT SRTM4, Jarvis et al., 2008). A) Mapa de situación; B y C) mapas mostrando los depósitos asimétricos y la migración fluvial. D) Fotografía del contacto entre las rocas metamórficas Variscas y los depósitos cenozoicos (falla de Golpejas). Representación estereográfica de que ilustra la relaciones entre la geometría de la falla, la cinemática y la esquistosidad. E) Esquema de la migración fluvial y las estructuras involucradas, que son compatibles con una orientación del tensor de esfuerzos de NNO-SSE a N-S.

tribution. Main streams orientation (such as the Agueda, Duero, Esla and Valderaduey rivers) (Fig. 11) is conditioned by the fault pattern as abrupt changes in main trunk direction and incision distribution reveal (Antón and Muñoz Martín, 2007; Antón et al., 2011).

In the WCB, N-S to NE-SW main faults seems to be responsible for the seismicity recorded in the area. The main example is the Esla fault where moderate seismicity, with magnitudes up to $4.2 \mathrm{Mw}$, occurs. Moment ten- sor focal mechanisms (Stich et al., 2003) evidence the seismogenic activity of an $\mathrm{N} 10^{\circ}$ trending left lateral strike slip fault moving under a N-S to NW-SE oriented maximum horizontal compressive stress.

Moreover, asymmetries in fluvial deposits distribution and lateral migration of valleys revealed faults movements during the Cenozoic or/and in the Quaternary. Structures controlling the deposits distribution asymmetries are mostly oriented NW-SE to N-S (Antón, 2004). 


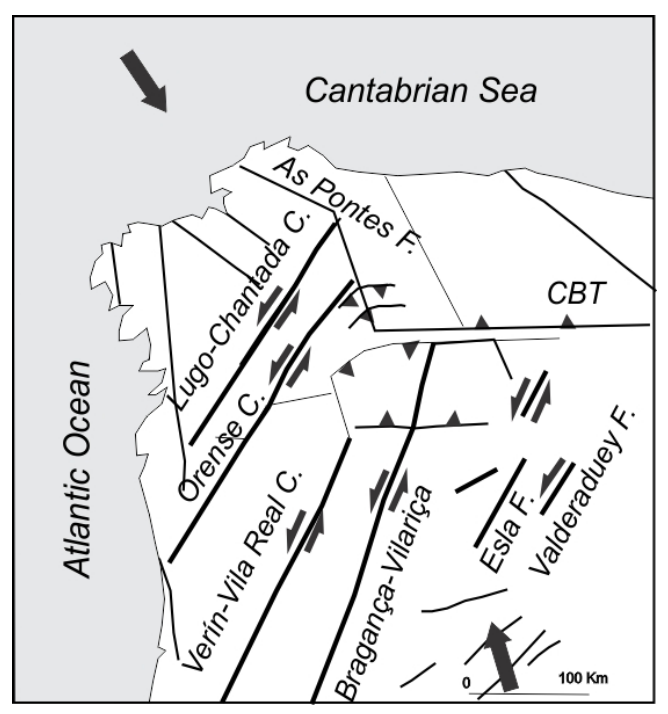

Fig. 11.- Sketch showing the fault orientations and faults that are potentially active under the current stress field.

Fig. 11.- Esquema mostrando las orientaciones de las fallas que son potencialmente activas bajo el tensor actual de esfuerzos.

\section{Conclusions}

The North-West and Central-West Iberian Peninsula correspond to intraplate regions located far away from the seismically active borders of the Iberian Peninsula. However, seismic sequences of moderate magnitude $(5.1 \mathrm{mb})$ have revealed the presence of active structures and potentially damaging earthquakes in this region.

After the analysis of the spatial distribution of seismicity and focal mechanisms, faults trending NE-SW to $\mathrm{N}-\mathrm{S}$ seem to be the responsible for most of the present seismicity.

Geomorfological and structural evidences of recent tectonic activity have been identified in tilted terraces, asymmetries in fluvial deposits distribution and drainage affections. Theses evidences are due to strike-slip faults trending NE-SW and N-S, and to northwest verging thrusts. All these structures can be reactivated under the inferred present stress field.

In the NW Iberian Peninsula the seismicity seems to be oriented following NE-SW fault corridors (e. g. Orense fault corridor) and the seismicity increased in Celanova (Orense) after the seismic crisis of Lugo indicating a southward migration of the activity.

Taking into account the horizontal maximum compression, and the evidences of recent activity, the potentially active structures are: 1) NE-SW to N-S strike slip faults; 2) Thrust trending NE-SW to ENE-WSW with NW vergence (Fig. 11).

\section{Acknowledgements}

The authors wish to thank J. Cabral and A. Casas for their comments and suggestions that have contributed to the improvement of the final version of the manuscript.

\section{References}

Adams, J., Wetmiller, R.J., Hasegawa, H.S., Drysdale, J.A. (1991): The first surface faulting from a historical intraplate earthquake in North America. Nature, 352, 617-619. doi:10.1038/352617a0.

Alonso, J. A., Pulgar, J. A., García-Ramos, J. C., Barba, P. (1996): Tertiary basins and Alpine tectonics in the Cantabrian Mountains (NW Spain). In: Friend, D. F., Dabrio, C. J. (eds.). Tertiary basins of Spain: the stratigraphic record of crustal kinematics. Cambridge University Press, Cambridge, 214-227.

Andeweg, B., de Vicente, G., Cloetingh, S., Giner, J., Muñoz-Martín, A. (1999): Local stress fields and intraplate deformation of Iberian Peninsula; variations in spatial and temporal interplay of regional stress sources. Tectonophysics 305, 153-164. doi:10.1016/S00401951(99)00004-9.

Antón L., Olaiz A., De Vicente G., Muñoz-Martín A. (2010b): Sismicidad y fallas con evidencias de actividad cuaternaria en el Centro-Oeste de Iberia. In: Insua, J.M. Martín-González, F. (eds.) Contribución de la Geología al Análisis de la Peligrosidad Sísmica. Sigüenza (Spain): 33-36.

Antón, L. (2004): Análisis de la fracturación en un área granítica intraplaca: el Domo de Tormes. http://www.ucm.es/BUCM/tesis/geo/ ucm-t26842.pdf. PhD Thesis Universidad Complutense de Madrid, Madrid: 195 p.

Antón, L., De Vicente, G. (2006): Tensor actual de esfuerzos y fallas potencialmente activas en el Domo de Tormes (NO de Iberia). Geogaceta 40, 11-14.

Antón, L., Muñoz-Martín, A. (2007): Controles tectonicos y estructurales de la incision fluvial en el centro-oeste de la cuenca del Duero, NO de Iberia. Geogaceta 43, 51-54.

Antón, L., Muñoz-Martín, A., De Vicente, G. (2010a): Alpine paleostress reconstruction and active faulting in western Iberia. Central European Journal of Geosciences 2, 152-164. doi: 10.2478/ v10085-010-0006-7.

Antón, L., Rodes, A., De Vicente, G., Pallas, R., Garcia-Castellanos, D., Stuart, F.M., Braucher, R., Bourles, D. (2011): Quantification of fluvial incision in the Duero Basin (NW Iberia) from longitudinal profile analysis and terrestrial cosmogenic nuclide concentrations. Geomorphology. doi: 10.1016/j.geomorph.2011.12.036.

Arenas R, Martínez-Catalán, J. R. (2003): Low-P metamorphism following a Barrovian-type evolution Complex tectonic controls for a common transition, as deduced in the Mondoñedo thrust sheet (NW Iberian Massif). Tectonophysics 365, 143-164. doi:10.1016/S00401951(03)00020-9.

Ares-Yanez, M., Gutierrez-Alonso, G., Diez-Balda, M.A., Alvarez, F. (1995): La prolongacion del despegue de Salamanca (segunda fase de deformacion Varisca) en el horst de Miruena (zona centro Iberica). Revista de la Sociedad Geológica de España 8, 175-191.

Arthaud, F., Matte, P. (1975): Les decrochements tardi-hercyniens du sud-ouest de l'Europe; geometrie et essai de reconstitution des conditions de la deformation. Tectonophysics 25, 139-171.

Arthaud, F., Matte, P. (1977): Late Paleozoic strike-slip faulting in southern Europe and northern Africa: Result of a right-lateral shear zone between the Appalachians and the Urals. Geological Society of America Bulletin 88, 1305-1320. doi: 10.1130/0016-7606. 
Barnolas, A., Pujalte, V. (2004): La Cordillera Pirenaica. In: Vera, JA (ed.), Geología de España IGME-SGE, Madrid: 233-343.

Cabral, J. (1989): An example of intraplate neotectonic activity, Vilarica Basin, Northeast Portugal. Tectonics 8, 285-303.

Cabral, J. (1995): Neotectonica em Portugal Continental. Mem. Inst. Geol. Mine 31, 263 p.

Cabral, J., Perea, H., Figueiredo, P., Besana-Ostman, G.M., Brum da Silveira, A., Cunha, P.P., Gomes, A., Lopes, F.C., Pereira, D., Rockwell., T. (2010): Preliminary results of a paleoseismological study of the Vilariça fault (NE Portugal). In: Insua J.M., Martín-González, F. (eds.), Contribución de la Geología al Análisis de la Peligrosidad Sísmica Sigüenza (Spain): 41-44.

Cabral, J., Ribeiro, A. (1993): Estudos de neotectonica em Portugal continental (mapa neotectonico). El Cuaternario en Espana y Portugal; Vol. 2. ITGE, Madrid.

Choukroune, P., Roure, F., Pinet, B. ECORS Pyrenees Team. (1990): Main results of the ECORS Pyrenees profile. Tectonophysics 173, 411-423. doi: 10.1016/0040-1951(90)90234-Y.

Crone, A., Machette, M.N., Bowman, R. (1992): Geologic investigations of the 1988 Tennant Creek, Australia, earthquakes. Implications for paleosismicity in stable continental regions. U.S Geological Survey Bulletin 3032,1-51.

De Vicente, G. (1988): Análisis poblacional de fallas. El sector de enlace Sistema Central-Cordillera Ibérica. $\mathrm{PhD}$, Universidad Complutense de Madrid, Madrid: $317 \mathrm{p}$.

De Vicente, G., Cloetingh, S., Muñoz-Martín, A., Olaiz, A., Stich, D., Vegas, R., Galindo-Zaldivar, J., Fernandez-Lozano, J. (2008): Inversion of moment tensor focal mechanisms for active stresses around the microcontinent Iberia: Tectonic implications. Tectonics 27, TC1009, doi: 10.1029/2006TC002093.

De Vicente, G., Giner, J.L., Muñoz-Martín, A., Gonzalez-Casado, J.M., Lindo, R. (1996): Determination of present-day stress tensor and neotectonic interval in the Spanish Central System and Madrid Basin, central Spain. Tectonophysics 266, 405-424. doi: 10.1016/ S0040-1951(96)00200-4.

De Vicente, G., Vegas, R. (2009): Large-scale distributed deformation controlled topography along the western Africa-Eurasia limit: Tectonic constrains. Tectonophysics 474, 124-143. doi: 10.1016/j. tecto.2008.11.026.

De Vicente, G., Vegas, R., Muñoz-Martín, A., Silva, P.G., Andriessen, P., Cloetingh, S., González-Casado, J.M., Van Wees, J.D., Álvarez, J., Carbó, A., Olaiz, A. (2007): Cenozoic thick-skinned deformation and topography evolution of the Spanish Central System. Global and Planetary Change 58, 335-381. doi: 10.1016/j.gloplacha.2006.11.042.

Diez-Balda, M.A., Vegas, R., Gonzalez-Lodeiro, F. (1990): Structure. In: R.D. Dallmeyer, E. Martínez-Garcia (eds.), Pre-Mesozoic geology of Iberia. Springer-Verlag, Berlin, Federal Republic of Germany: 172-188.

Diez-Balda, M.A., Vegas, R., Liso-Rubio, M.J. (1992): La estructura del dominio de los pliegues verticales de la zona centro iberica. In: M.J. Liso Rubio (ed.), Paleozoico inferior de Ibero-America. Universidad de Extremadura, Badajoz, Spain: 523-534.

Escuder, J., Diez-Montes, A., Carrasco, R.M., Sanz-Santos, M.A. (2000): Mapa Geológico de Aldeadavila de La Ribera. Instituto Geologico y Minero de España (IGME), Madrid.

Galindo-Zaldivar, J., Jabaloy, A., Serrano, I., Morales, J., GonzalezLodeiro, F., Torcal, F. (1999): Recent and present-day stresses in the Granada Basin (Betic Cordilleras); example of a late Miocenepresent-day extensional basin in a convergent plate boundary. Tectonics 18, 686-702. doi: 10.1029/1999TC900016.

Galindo-Zaldivar, J., Gonzalez-Lodeiro, F., Jabaloy, A. (1993): Stress and palaeostress in the Betic-Rif cordilleras (Miocene to the present). Tectonophysics 227, 105-126. doi: 10.1016/00401951(93)90090-7.

Gallastegui, J., Pulgar, J. A., Gallart, J. (2002): Initiation of an active margin at the North Iberian continent ocean transition. Tectonics, 21: 1501-1514. doi:10.1029/2001TC901046.

González Casado, J. M., Giner., J. (2000): Relaciones entre fallas y sismicidad en el noroeste peninsular. Geogaceta 28,71-75.

Gupta, H.K. 1993. The deadly Latur earthquake. Science, 262:16661667. doi:10.1126/science.262.5140.1666.

Gutierrez-Claverol, M., López-Fernández, C., Alonso, J. L. (2006): Procesos neotectónicos en los depósitos de rasa en la zona de Canero (Occidente de Asturias). Geogaceta 40, 75-78.

Heredia, N., Rodríguez-Fernández, L. R., Vegas, R., De Vicente, G., Cloetingh, S., Giner, J. y González-Casado, J. M. (2004): Cadenas Cenozoicas del Noroeste peninsular. In: J.A. Vera (ed.), Geología de España, SGE-IGME, Madrid: 619-621.

Herraiz, M., De Vicente, G., Lindo-Naupari, R., Giner, J., Simon, J.L., Gonzalez-Casado, J.M., Vadillo, O., Rodriguez-Pascua, M.A., Cicuendez, J.I., Casas, A., Cabanas, L., Rincon, P., Cortes, A.L., Ramirez, M., Lucini, M. (2000): The Recent (upper Miocene to Quaternary) and present tectonic stress distributions in the Iberian Peninsula. Tectonics 19, 762-786. doi: 10.1029/2000TC900006

Iglesias-Ponce de Leon, M., Choukroune, P. (1980): Shear zones in the Iberian arc. Journal of Structural Geology 2, 63-68. doi:10.1016/0191-8141(80)90035-8.

Jarvis, A., Reuter, H.I., Nelson, A., Guevara, E. (2008): Hole-filled seamless SRTM data V4. (International Centre for Tropical Agriculture (CIAT), available from http://srtm.csi.cgiar.org.

Liesa, C.L., Simon, J.L. (2009): Evolution of intraplate stress fields under multiple remote compressions; the case of the Iberian Chain (NE Spain). Tectonophysics 474, 144-159. doi: 10.1016/j.tecto.2009.02.002

López-Plaza, M., Gonzalo, J.C. (1986): Los granitos hercinicos como indicadores de la evolucion estructural del Macizo Hesperico. Hercynica 2, 57-64.

López, C. (2008): Actividad sísmica, zonación sismotectónica y riesgo sísmico en el NO de la Península Ibérica. A Coruña : Instituto Universitario de Geología, 2008.

López, C., Pulgar, J.A., Gallart, J., González, J.M, Díaz, J., M. Ruíz. (2004a): Actividad sísmica en el noroeste de la Peninsula Ibérica observada por la red sísmica local del Proyecto GASPI (19992002). Trabajos de Geología 24, 91-106.

López, C., Pulgar, J.A., Gallart, J., González, J.M., Díaz, J., Ruíz, M. (2004b): Sismicidad y tectónica en el área de Becerreá-Triacastela (Lugo, NO España). Geogaceta 36, 51-54.

Martínez-Catalán, J. R., Pérez-Estaún, A., Bastida, F., Pulgar, J. A., Marcos, A. (1990): West Asturian-Leonese Zone: Structure. In: Dallmeyer, R D, Martínez-García, E (eds.), Pre-Mesozoic Geology of Iberia. Springer-Verlag, Berlín: 103-114.

Martínez-Fernandez, F.J. (1974a): Estudio del área metamófica del NW de Salamanca (Cordillera Herciniana), España. Trabajos de Geología 7, 3-60.

Martínez-Fernandez, F.J. (1974b): Petrografía, estructura y geoquímica de los diferentes tipos de granitos del NW de Salamanca (Cordillera Herciniana, España). Trabajos de Geología 7, 61-141.

Martínez, F.J. (1977): Données sur le métamorphisme régional hercynien dans le dôme du Tormes (provinces de Salamanca et Zamora, Espagne). Geol Rundsch 66, 91-98.

Martínez-Díaz, J.J., Capote, R., Tsige, M., Villamor, P., Martín-González, F., Insua, J.M. (2006): Seismic triggering in a stable continental area: The Lugo 1995-1997 seismic sequences (NW Spain). Journal of Geodynamics 41, 440-449. doi: 10.1016/j.jog.2006.01.001.

Martínez-Graña, A., Goy, J. L., Zazo, C. (2000): Actividad tectónica 
en el NO peninsular, en base a los registros costeros en los últimos 130.000 años (Rías Arosa-Pontevedra, Galicia). Geo-Temas 1, 263266.

Martín-González, F. (2005): Tectónica alpina, neotectónica y sismotectónica en la terminación occidental de los relieves cantábricos (Macizo Ibérico). Marco tectónico de las crisis sísmicas de Lugo. PhD Thesis. Universidad Complutense. Madrid: 313 p.

Martín-González, F. (2009): Cenozoic tectonic activity in a Variscan basement: Evidence from geomorphological markers and structural mapping (NW Iberian Massif). Geomorphology 107, 210-225. doi: 10.1016/j.geomorph.2008.12.008.

Martín-González, F., Barbero, L., Capote, R., Heredia, N., Gallastegui, G. (2011): Interaction of two successive Alpine deformation fronts: constraints from low-temperature thermochronology and structural mapping (NW Iberian Peninsula). International Journal of Earth Sciences. doi: 10.1007/s00531-011-0712-9.

Martín-González, F., Heredia N. (2011a): Complex tectonic and tectonostratigraphic evolution of an Alpine foreland basin: The western Duero Basin and the related Tertiary depressions of the NW Iberian Peninsula _Tectonophysics 502, 75-89. doi:10.1016/j.tecto.2010.03.002

Martín-González, F., Heredia, N. (2011b): Geometry, structures and evolution of the western termination of the Alpine-Pyrenean Orogen relief (NW Iberian Peninsula). Journal of Iberian Geology 37, 102-120. doi: 10.5209/rev_JIGE.2011.v37.n2.1.

Martín-González, F., Insua, J. M., Capote, R., Martínez-Díaz, J.J. (2003): Estudio gravimétrico de la cuenca terciaria de Sarria (LugoEspaña). Cuadernos Laboratorio Xeolóxico de Laxe 28, 329-341.

Martín-González, F., Insua, J.M., Capote, R., Martínez, J.J. (2006): The seismic sequences of Sarria-Triacastela-Becerreá (1995-1997): Geological constraints. Proceedings V Asamblea-Hispano Portuguesa de Geodesia y Geofisica, Sevilla: 1-4.

Martín-Serrano, A., Mediavilla R., Santisteban, J.I. (1996): Northwestern Cenozoic record: present knowledge and the correlation problem. In: Friend, D. F., Dabrio, C. J. (eds.), Tertiary basins of Spain: the stratigraphic record of crustal kinematics. Cambridge University Press, Cambridge: 237-246.

Muir Wood R., Mallard, D.J. (1992): When is a fault extinct? Journal of the Geological Society of London, 149: 251-255. doi:10.1144/ gsjgs.149.2.0251.

Muñoz, J. A. (1992): Evolution of a continental collision belt: ECORS-Pyrenees crustal balanced section, In: K. R. McClay (ed.), Thrust Tectonics, London, Chapman and Hall: 235-246.

Muñoz, J. A. (2002): Alpine tectonics I: the Alpine system north of the Beltic Cordillera: The Pyrenees. In: W. Gibbons, T. Moreno (eds.), The Geology of Spain, Geological Society, London: 370-385.

NCSE-02. (2002): Norma de construcción sismorresistente: Parte general y edificación. BOE 244:35898-35967.

NCSE-94. (1995): Norma de construcción sismoresistente: Parte general y edificación, en Acciones en la edificación. Serie normativas. Madrid: MOPTMA: 79-135.

Olaiz, A.J., Muñoz-Martín, A., de Vicente, G., Vegas, R., Cloetingh, S. (2009): European continuous active tectonic strain-stress map. Tectonophysics 474, 33-40. doi: 10.1016/j.tecto.2008.06.023.

Pagés, J. L., Vidal Romaní, J. R. (1997): Evolución Neógena de la Cuenca Baja del Tambre. Cadernos Laboratorio Xeolóxico de Laxe 22, 121-132.
Pondrelli, S., A. Morelli, G. Ekström, S. Mazza, E. Boschi y A.M. Dziewonski. (2002): European-Mediterranean regional centroidmoment tensors: 1997-2000. Physics of the Earth and the Planetary Interiors 130, 71-101. doi: 0.1016/S0031-9201(01)00312-0.

Rockwell, T., Fonseca, J., Madden, C., Dawson, T., Owen, L.A., Vilanova, S., Figueiredo, P. (2009): Palaeoseismology of the Vilarica Segment of the Manteigas-Braganca Fault in northeastern Portugal. Geological Society Special Publication 316, 237-258. doi: 10.1144/SP316.15

Rodríguez-García, A., Quintana, L., González-Menédez, L., SuárezRodríguez, A. (2006): Neotectónica en el norte de Galicia: Fallas inversas de actividad cuaternaria en la cuenca fluvial del Alveolo de Alfoz, Lugo. Geogaceta 40, 23-26.

Rueda, J., Mezcua, J. (2001): Sismicidad, sismotectónica y peligrosidad sísmica en Galicia. Madrid: Instituto Geográfico Nacional. Madrid: 64 p.

Santanach, P. (1994): Las cuencas terciarias gallegas en la terminación occidental de los relieves pirenaicos. Cadernos del Laboratorio Xeológico de Laxe 19, 57-71.

Santisteban, J.I., Martín-Serrano, A. (1996): Alpine tectonics framework of south-western Duero basin. In: D. F. Friend, C. J. Dabrio (eds.), Tertiary basins of Spain: the stratigraphic record of crustal kinematics. Cambridge University Press, Cambridge: 9-14.

Santisteban, J.I., Mediavilla, R., Martín-Serrano, A. (1991): El Paleogeno del sector suroccidental de la cuenca del Duero; nueva division estratigrafica y controles sobre su sedimentacion. Acta Geologica Hispanica 26, 133-148.

Srivastava, S.P., Schouten, H., Roest, W.R., Klitgord, K.D., Kovacs, L.C., Verhoef, J., Macnab, R.F. (1990): Iberian Plate kinematics; a jumping plate boundary between Eurasia and Africa. Nature 344, 756-759. doi: 10.1038/344756a0

Stich, D., Ammon, C.J., Morales, J. (2003): Moment tensor solutions for small and moderate earthquakes in the Ibero-Maghreb region. Journal of Geophysical Research 108(B3). doi: 10.1029/2002JB002057

Teixell, A. (1998): Crustal structure and orogenic material budget in the west-central Pyrenees. Tectonics 17, 395-406. doi:10.1029/98TC00561.

Vegas, R. (2005): Deformacion alpina de macizos antiguos; el caso del Macizo Iberico (Hesperico). Boletín de la Real Sociedad Española de Historia Natural, Seccion Geologica 100, 39-54.

Villamor, M.P. (2002): Cinemática Terciaria y Cuaternaria de la Falla de Alentejo-Plasencia y su Influencia en la Peligrosidad Sísmica del Interior de la Península Ibérica (Tertiary and Quaternary kinematics of the Alentejo-Plasencia and its influence on sesimic hazard of hte interior of Iberian Peninsula; in Spanish). PhD Thesis, University Complutense, Madrid (Spain): 343 p.

Villamor, P., Capote, R., Stirling, M.W., Tsige, M., Berryman, K.R., Martínez-Díaz, J.J., Martín-González, F. (2012) Contribution of active faults in the intraplate area of Iberia to Seismic Hazard: the Alentejo-Plasencia Fault. Journal of Iberian Geology 38. doi: 10.5209/rev_JIGE.2012.v38.nl.39207.

Villar-Alonso, P., Diez-Montes, A., Mediavilla-Lopez, R., Herrero-Hernandez, A., Sanz-Santos, M.A. (2000): Mapa Geológico 1:50.000 Almeida. Instituto Geologico y Minero de Espana (IGME), Madrid. 